\title{
LSAスコア低得点化に関連する要因
}

\section{Investigation of Factors Resulting in Low Scores in the Life Space Assessment}

\author{
松田 憲亮 ${ }^{1,4)}$ 宗形 龍太朗 ${ }^{2)}$ 池田 翔 ${ }^{3)}$ 中原 雅美 ${ }^{1,4}$ \\ 永井良治 ${ }^{1)}$ 岡本 龍北 ${ }^{1)}$ 池田 拓郎 ${ }^{1)}$ \\ Kensuke MATSUdA $^{1,4)}$, Ryutarou MUNAKATA ${ }^{2)}$, Shou IKEDA ${ }^{3)}$, MASAMi NAKAHARA ${ }^{1,4)}$, \\ YOSHIHARU NAGAI ${ }^{1)}$, RYUII OKAMOTO ${ }^{1)}$, TAKUROU IKEDA ${ }^{1)}$ \\ ${ }^{1)}$ Department of Physical Therapy, School of Health Sciences at Fukuoka, International University of Health and Welfare: 137-1 \\ Enokizu, Okawa-shi, Fukuoka 831-8501, Japan.TEL+81944-89-2000E-mail: k.matsuda@iuhw.ac.jp \\ ${ }^{2)}$ Department of Rehabilitation, Long Term Care Health Facility Dream-Hills Takiyama \\ ${ }^{3)}$ Department of Rehabilitation, Takaki Hospital \\ 4) Division of Cognitive Neuropsychology Graduate School of Medicine, Saga University
}

Rigakuryoho Kagaku 30(6): 977-980, 2015. Submitted Jul. 10, 2015. Accepted Aug. 21, 2015.

ABSTRACT: [Purpose] The purpose of this study was to investigate the factors resulting in low scores in the life space assessment (LSA). [Subjects] The subjects were 30 elderly persons receiving secondary care prevention. [Methods] The subjects were divided into two groups: a LSA high-scoring group, and a LSA low-scoring group. Each of the evaluation values were examined for significant differences using Student's $t$-test. Logistic regression analysis was used to determine the factors resulting in low scores in the LSA. [Results] Significant differences were observed between the LSA high-scoring group and the low-scoring group in 4 evaluation items. Logistic regression analysis showed the modified falls efficacy Scale (MFES) score was significantly associated with low scores in the LSA. The MFES score showed the relevance of knee extension strength, TUG, the coefficient of variation of stride time, and local stability of trunk acceleration (vertical direction). [Conclusion] Falls self-efficacy showed the relevance of knee extension strength, ability to move, and instability during walking, suggesting that falls self-efficacy was a factor of low scores in the LSA.

Key words: life space assessment, LSA low-scoring, factor analysis

要旨：〔目的〕Life Space Assessment（LSA）低得点化に関与する要因を明らかにすることとした。〔対象〕2 次介護 予防対象 30 名を対象とした. 〔方法〕LSA 高得点群と低得点群の 2 群に分け, 各評価項目の得点の平均值における 独立 2 群間の差の検定, 各評価項目得点間の関連性, LSA 低得点に関与する要因分析を行った。〔結果〕LSA 低得点 群は高得点群と比較し，4つの評価項目得点の平均值に有意差を示した．LSA 低得点の関連要因として転倒自己効力 感得点が示唆された. 転倒自己効力感得点は膝伸展筋力, Timed Up and Go Test, 歩行周期変動率, 歩行中の体幹上 下方向加速度との関連性を示した。〔結語〕転倒自己効力感は膝伸展筋力, 移動能力, 歩行中の不安定性との関連性 を示し, LSA 低得点化の要因であることが示唆される。

キーワード：LSA，低得点化，要因分析

\footnotetext{
1) 国際医療福祉大学 福岡保健医療学部＼cjkstart理学療法学科:福岡県大川市榎津 137-1 ( ₹ 831-8501) TEL 0944-89-2000

2) 介護老人保健施設ドリームビルズ 滝山リハビリテーション科

3) 高木病院リハビリテーション部

4) 佐賀大学 医学系研究科

受付日 2015 年 7 月 10 日 受理日 2015 年 8 月 21 日
} 


\section{I.はじめに}

高齢者の活動能力低下は日常の行動範囲の狭小化と関 連性が高く, 生活空間の評価と関連要因の検討が行われ ている. 生活空間は「日常の活動で一定期間に移動した 範囲」と定義され，その評価に生活移動尺度（Life Space Assessment; 以下, LSA）による点数化が多く用 いられている. また先行研究1)では日本語版 LSA の基 準関連妥当性と構成概念妥当性が検討され, LSA 得点 は介護予防が必要とする日本人高齢者の生活空間の測定 尺度として有用であることが報告されている。日本理学 療法士協会では, Timed Up and Go Test (以下, TUG) との併用で高齢者への介入指標として用いられてい る2)。また二次介護予防対象高齢者に扔ける転倒予測指 標として, LSAの有用性や転倒に対するカットオフ值 が検討されている3). 本研究では転倒に対するLSAカッ トオフ值 3 をを用いて LSA 高得点群と低得点群の 2 群に 分け, それらの間で運動機能, 移動能力, 転倒自己効力 感を比較することにより LSA 低得点化に関与する因子 を明らかにすることを目的とした。

\section{II. 対象と方法}

1. 対象

対象は筋力増強事業に参加した 2 次介護予防対象高齢 者の男性 6 名, 女性 24 名の計 30 名（年齢 $78.0 \pm 5.3$ 歳 平均 \pm 標準偏差）とした。また計測当日の問診から身 体機能評価測定等の内容を理解できない程の重度の認知 機能低下がある者や視力障害や身体機能障害による全て の項目を測定できなかった者, 服薬等の影響があると 判断した者は除外した。対象者には本研究の内容を十分 に説明し紙面にて同意を得た。な扮，本研究は国際医療 福祉大学の倫理委員会の承認（10-42）を得て実施した.

\section{2. 方法}

質問紙調查は測定当日の体調, 転倒状況, 運動習慣, 服薬状況等を本人との面接での聴取によるものとした。 その中で過去 1 年間の転倒の有無を確認した。過去 1 年 間の転倒状況は, 調査日以前の 1 年間の転倒状況を対象 者が想起して「はい」または「いいえ」の二件式の回答 およびその転倒回数とした。な沶転倒の定義は，「自分 の意思ではなく, 不注意により膝, 上肢（手や腕など）, あるいは尻や腰などの身体部分が床面や地面などのより 低いレベルに接触する場合」とした 4 ).

LSA の評価は Bakerらによって開発されたLSA スコ ア5）日本語版に修正したスケール2）用いた，LSA スコアは過去 1 カ月間の活動範囲, 活動頻度および自立 度から点数を算出するものである. 活動範囲は寝室, 自 宅内, 自宅外, 自宅近隣 $(800 \mathrm{~m}$ 以内 $)$, 町内 $(800 \mathrm{~m}$

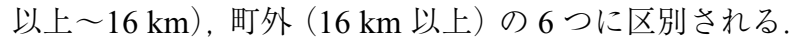
各活動範囲への外出の有無, 外出頻度, 方法（自立, 物 的介助, 介助) により点数化し, 最終的な点数は各活動 範囲点数の合計にて算出した。また LSA 得点は 120 点 満点で高い程生活活動量が高いことを示す指標である.

LSA のカットオフ值を基準に高得点群（15名）と低 得点群（15名）の2 群に分け, 年齢, 身長, 体重, BMI に加え, 運動機能, バランス能力, 移動能力, 転 倒自己効力感を計測した.

運動機能抢よび静的バランス能力の評価として膝関節 伸展筋力, 握力, 長座体前屈, 片脚起立時間 (開眼 - 閉 眼）を計測した，膝伸展筋力は Hand-held dynamometer （ $\mu$ Tas F-1，アニマ製）を用い測定した。この筋力には, 膝関節屈曲 $90^{\circ}$ に扔ける最大努力下での等尺性膝伸展筋 力を 2 回測定し, 最大值を採用した。ささらに体重で除す ことで筋力の正規化を行った.

握力, 長座位体前屈, 開眼片脚起立時間の測定は, 文 部科学省高齢者用新体力テスト 6)に従い実施した。長 座位体前屈は, デジタル長座位体前屈計 (竹井機器製) を用いて測定した。長座位体前屈の開始肢位は長座位を とり, 殿部, 背部, 後頭部が壁につけ, 上肢は肩幅の広 さで肘を伸ばし，デジタル長座位体前屈計の上に両手を 置くように指示した，壁に臂部をつけ，両膝を曲げない まま，デジタル長座位体前屈計を前方に移動させて計測 を行った，計測は 2 回行い，最大值を採用した。また閉 眼起立時間については閉眼片足立ち位で姿勢保持できる 時間の上限を 120 秒としてデジタルストップウォッチ を使用して左右各 2 回行い, その最長時間を代表値とし た。この際, 対象者は裸足, 両上肢は体側につけるよう に指示した。

移動能力の評価として Timed up and go test（以下, $\mathrm{TUG}, \quad 10 \mathrm{~m}$ 歩行速度, 歩行周期変動率, 歩行中の体 幹加速度 Root Mean Square value（以下, RMS）を計測 した. $10 \mathrm{~m}$ 歩行速度の測定は加速路と減速路をそれぞ れ $3 \mathrm{~m}$ ずつ設けた合わせて約 $16 \mathrm{~m}$ の直線路を設け, 中 間の $10 \mathrm{~m}$ 所要時間を計測した。測定は 2 回実施し, 最 小值を代表值とした.

歩行周期変動率および歩行中の重心動摇の測定は先行 研究7)に準じて行い, 第 3 腰椎棘突起に加速度計 （MA3-04AC；マイクロストーン社製）を装着し行った。 対象者が約 $16 \mathrm{~m}$ の直進路で快適歩行を 2 回実施し, そ の歩行中の加速度データから 1 歩行周期時間を算出し た。連続する 1 歩行周期時間から変動倸数を算出し, 歩 行周期変動率とした．歩行中の体幹加速度については $10 \mathrm{~m}$ 歩行中の加速度データから 5 歩行周期分のデー夕 を抽出し, 上下, 左右, 前後方向の RMS を算出して, これを歩行中の重心動摇の指標とした．RMS は歩行速 度の 2 乗で除すことで正規化を行った。

転倒恐怖感の評価には，転倒自己効力感の指標である 
表 1 LSA 低得点群と高得点群間での評価項目の比較

\begin{tabular}{|c|c|c|}
\hline & LSA 低得点群 & LSA 高得点群 \\
\hline 年齢（age） & $79.3 \pm 4.8$ & $76.7 \pm 5.6$ \\
\hline 身長（m） & $1.5 \pm 0.8$ & $1.5 \pm 0.9$ \\
\hline 体重（kg） & $54.0 \pm 14.1$ & $50.2 \pm 10.7$ \\
\hline BMI & $22.9 \pm 4.6$ & $20.1 \pm 3.7$ \\
\hline 膝伸筋（Nm/kg） & $0.3 \pm 0.1$ & $0.4 \pm 0.1^{*}$ \\
\hline 握力（kg） & $23.1 \pm 4.7$ & $25.8 \pm 8.3$ \\
\hline 長座位体前屈（cm） & $33.2 \pm 6.9$ & $32.6 \pm 7.9$ \\
\hline 開眼片脚立位時間（sec） & $6.3 \pm 7.5$ & $16.6 \pm 18.3$ \\
\hline 閉眼片脚立位時間（sec） & $2.6 \pm 1.8$ & $2.0 \pm 0.9$ \\
\hline Timed Up and Go Test（sec） & $8.7 \pm 2.7$ & $6.7 \pm 1.1^{*}$ \\
\hline $10 \mathrm{~m}$ 歩行速度 $(\mathrm{m} / \mathrm{sec})$ & $1.3 \pm 0.4$ & $1.5 \pm 0.2$ \\
\hline 歩行周期変動率（％） & $2.8 \pm 1.8$ & $1.7 \pm 0.6^{*}$ \\
\hline \multicolumn{3}{|l|}{ 歩行中の体幹加速度 } \\
\hline 上下方向 RMS & $2.2 \pm 0.5$ & $1.9 \pm 0.4$ \\
\hline 左右方向 RMS & $1.1 \pm 0.3$ & $1.0 \pm 0.1$ \\
\hline 前後方向 RMS & $1.5 \pm 0.4$ & $1.4 \pm 0.3$ \\
\hline MFES（score） & $104.6 \pm 25.2$ & $127.7 \pm 13.3^{*}$ \\
\hline LSA（score） & $37.7 \pm 7.3$ & $59.8 \pm 13.7^{*}$ \\
\hline
\end{tabular}

RMS, root mean square; MFSE, Modified Falls Efficasy Scale; LSA, Life Space Assessment; ns Data are mean \pm SE; *:p $<0.05$.

Modified Falls Efficacy Scale（以下, MFES）を用いて

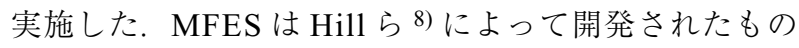
を日本語版に修正したスケールを用いた，MFES は基本 的 ADL および手段的 ADL から構成されていることと 地域で生活する高齢者本人の屋内・屋外活動をも含む評 価尺度である点が特徴である ${ }^{9)}$. 各項目について 0-10 得点で記入させ, その合計得点が低いほど転倒恐怖感が 強いことを意味する。転倒恐怖感について 140 点満点 をなし，139点以下をありと判断した.

統計処理には SPSS statistics 22 (IBM 製)を使用した。 LSA 高得点群と低得点群に対し運動機能, バランス能 力, 移動能力, 転倒自己効力感について独立 2 群間の平 均值の差の検定を用い比較検討した。各評価項目間の関 連性についてはPearsonによる相関分析を行った。また 独立 2 群の差の検定において有意であった評価項目を独 立変数, LSA 得点の高低を従属変数とするロジスティッ ク回帰分析を行い, LSA 低得点に関与する要因（評価 項目）の検討およびオッズ比を求めた. 各独立変数間で の多重共線性の影響を少なくするため, 事前に相関関係 を調査し，高い相関関係 $(\mathrm{r} \geqq 0.8)$ があった場合はどち らかの項目を変数から除外した，有意水準はすべて $5 \%$ 未満とした。

\section{III. 結 果}

LSA 低得点群と高得点群間で基本属性である年齢, 身長, 体重, BMI, 男女比には有意差は認められなかっ
表 2 ロジスティック回帰分析によるLSA 低 得点に関わる因子の評価

\begin{tabular}{lc}
\hline $\begin{array}{c}\text { 変数 } \\
\text { (単位変化量 })\end{array}$ & $\begin{array}{c}\text { オッズ比 } \\
(95 \% \text { 信頼区間 })\end{array}$ \\
\hline MFES スコア $(1$ 点 $)$ & $1.07(1.01-1.13) *$ \\
\hline$*$ p $<0.05$. &
\end{tabular}

た。過去 1 年間の転倒経験者の割合は LSA 高得点群で

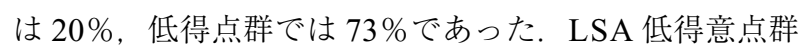
は高得点群と比較して 4 評価項目（膝関節伸展筋力, TUG, 歩行周期変動率, MFES 得点) においてそれぞ れの平均に有意に高いあるいは低い值を示した（表 1). ロジスティック回帰分析の結果, LSA 低得点に関与す る要因として MFES 得点が挙げられた。オッズ比は 1.07 （95\%信頼区間 1.01-1.13）であった（表2）。さらに MFES と他の評価項目との関連性を示す相関係数は, BMI $(-0.36)$, 膝伸展筋力 $(0.32)$, TUG $(-0.33)$, 歩行周期変動率 $(-0.48)$, 歩行中の体幹加速度上下方 向 RMS（-0.43）であった.

\section{IV. 考 察}

先行研究 3)より LSA 得点は転倒予測指標として有用 性を示し（感度 87\%, 特異度 69\%, オッズ比 $1.15(95 \%$ 信頼区間 1.04-1.27)), カットオフ值は 47.3 点であった. 本研究ではこのカットオフ值を用いて対象者をLSA 低 
得点群と高得点群の 2 群へ分けた. カットオフ值より低 い点数を示す LSA 低得点群に含まれる者は庭や隣接す る家屋程度を生活範囲としていることがわかった。また LSA 低得点群における転倒未経験者（全体の 27\%）で は, 生活空間を狭小化することで転倒することを避けて いることが聴取からわかった。

一方, LSA 低得点群は高得点群と比較し膝伸展筋力, 動的バランス能力, 移動能力, MFESにおいて得点の平 均值が有意に低かった。健常高齢者の姿勢の不安定性に 対して筋力低下が寄与すること, 筋力低下とバランス障 害との間の関連性のあることが報告されている ${ }^{10)}$. LSA 低得点群の筋力の有意な低下は, バランス能力や 歩行中の動的バランスの低さと関連性が高いことが推測 される。また LSA 低得点群の歩行周期変動率 $2.8 \%$ は, 転倒経験者の歩行周期変動率 $3.0 \%$ 11) に近く, 転倒リ スクが高いことが示唆される。また歩行分析において上 下方向の RMS は有用であり，身体重心との有意な相関 を持つことが報告されている 12). LSA 低得点群では歩 行中の体幹加速度である上下方向 RMS が有意に増大寸 る傾向にある。このことは歩行中の重心制御が不安定で あることを意味している。

ロジスティック回帰分析結果から LSA 低得点を説明 する要因として MFES 得点のみが有用な項目であった。 MFES 得点は転倒恐怖感と外出自肃との関連性が強いこ とが報告されており 13)，本研究の結果と類似したもの であった。 また MFES 得点は 14 項目の生活動作に対す る自己効力感を示すものであり, 生活動作に関与する運 動機能や移動能力等の影響が高いと考えられる.MFES は BMI, 膝伸展筋力, $\mathrm{TUG}$, 歩行周期変動率, 歩行中 の体幹加速度上下方向 RMS との間に有意な相関性を示 した。姿勢制御能力の中でも重心移動能力ゃ不安定な状 況下での姿勢修正, 保持する能力は加齢により低下しや すく, 転倒恐怖感や生活活動量との関連性が高い 14). さらにLSA 得点で評価された生活空間は運動機能へ影 響を与え，運動機能もまた生活空間に影響を与えるよう な相互作用があると報告されている15)。本研究では MFES 得点は BMI, 膝伸展筋力, 移動能力および歩行 安定性との関連性を持ち, LSA を低得点化させる要因 の 1 つであることが示唆される.

本研究は高齢者の生活空間尺度について, 主に運動機 能や移動能力などに着目した検討である。先行研究 16) では一般健康状態, 物的 ·人的環境, 趣味的活動等を含 めた包括的分析が必要と報告されており, 今後の課題と したい. また, 本研究のサンプルサイズは小さく, 研究 結果の解釈は慎重に行う必要がある.

\section{引用文献}

1) 原田和宏, 島田裕之, Patricia $S$-他 : 介護予防事業に参加 した地域高齢者における生活空間 (life-space) と点数化評価 の妥当性の検討. 日本公衛誌, 57(7): 526 .

2) 理学療法士協会: http://www.japanpt.or.jp/esas/03_note/ index.html（閲覽日2015年4月 1 日）。

3) 池田 翔, 松田憲亮, 中原雅美 - 他 : 転倒予測指標として の応用歩行予備能力の有用性の検討. 理学療法科学, 2015, 30(6): 973-977.

4) Gibson MJ: Falls in later life. Improving the Health of Older People. A World View. Oxford University Press, Oxford, 1990, 296-315.

5) Baker PS, Bodner EV, Allman RM: Measuring life-space mobility in community dwelling older adults. J Am Geriatr Soc, 2003, 51: 1610-1614.

6) 文部科学省スポーツ・青年局：H22 年度体力・運動能力調 查報告書・新体力テスト実施要項. 2010: 5-12.

7) 山田 実, 平田総一郎, 小野 玲- 他: 体幹加速度由来歩 容指標による歩容以上の評価. 理学療法学, 2006, 33(1): 14-21.

8) Hill KD, Schwart JA, Kalogerropouls AJ, et al.: Fear of falling revisited. Arch Pyhs Med Rehabil,1996, 77(10): 1025-1029.

9) 近藤 敏, 宮前珠子, 石橋陽子・他：高齢者における転倒 恐怖感. 総合リハ, 1999, 27(8): 775-780.

10) Orr R: Contribution of muscle weakness to postural instability in the elderly. A systematic review. Eur J Phys Rehabil Med, 2010, 46(2): 183-220.

11) Hausdorff JM, Rios DA, Edelberg HK, et al.: Gait variability and fall risk in community-living older adults: a 1-year prospective study. Arch Phys Med Rehabil, 2001, 82: 1050-1056.

12) Osaka H, Shinkoda K, Watanabe $S$, et al.: Validity of evaluation index utilizing three components of trunk acceleration during walking. J Phys Ther Sci, 2013, 25(1): 81-84.

13) 村上泰子, 柴 喜崇, 渡辺修一郎·他：地域在住高齢者に 打ける転倒恐怖感に関連する因子. 理学療法科学, 2008, 23(3): 413-418.

14) 小柏進也，池添冬芽，建内宏重・他：高齢者の姿勢制御能 力と転倒恐怖感抢よび生活活動量との関連. 理学療法学, 2010, 37(2): 78-84.

15）日下隆一, 原田和宏，金谷さとみ・他：介護予防に扔ける 総合的評価の研究. 理学療法学, 2008, 35(1): 1-7.

16) 島田裕之, 牧迫飛雄馬, 鈴川芽久美 - 他 : 地域在住高齢者 の生活空間の拡大に影響を与える要因：構造方程式モデリ ングによる検討. 理学療法学, 2009, 36(7): 370-376. 